\title{
Article \\ Neurological Impacts of Chronic Methylmercury Exposure in Munduruku Indigenous Adults: Somatosensory, Motor, and Cognitive Abnormalities
}

\author{
Rogério Adas Ayres de Oliveira ${ }^{1}$, Bruna Duarte Pinto ${ }^{1}$, Bruno Hojo Rebouças ${ }^{1}$, Daniel Ciampi de Andrade ${ }^{1}$, \\ Ana Claudia Santiago de Vasconcellos ${ }^{2}$ and Paulo Cesar Basta ${ }^{3, *(B)}$ \\ 1 Centro de Dor, Departamento de Neurologia, Hospital das Clínicas, Faculdade de Medicina, Universidade de \\ São Paulo (USP), São Paulo 05403-000, Brazil; roger.adas.doc@gmail.com (R.A.A.d.O.); \\ brunaduartencl@gmail.com (B.D.P.); bruhojo@hotmail.com (B.H.R.); ciampi@usp.br (D.C.d.A.) \\ 2 Laboratório de Educação Profissional em Vigilância em Saúde, Escola Politécnica de Saúde Joaquim Venâncio, \\ Fundação Oswaldo Cruz (EPSJV/Fiocruz), Rio de Janeiro 21040-900, Brazil; anacsvasconcellos@gmail.com \\ 3 Departamento de Endemias Samuel Pessoa, Escola Nacional de Saúde Pública, Fundação Oswaldo \\ Cruz (ENSP / Fiocruz), Rio de Janeiro 21041-210, Brazil \\ * Correspondence: paulobasta@gmail.com; Tel.: +55-21-2598-2503
}

Citation: Oliveira, R.A.A.d.; Pinto, B.D.; Rebouças, B.H.; Ciampi de Andrade, D.; Vasconcellos, A.C.S.d.; Basta, P.C. Neurological Impacts of Chronic Methylmercury Exposure in Munduruku Indigenous Adults: Somatosensory, Motor, and Cognitive Abnormalities. Int. J. Environ. Res. Public Health 2021, 18, 10270. https://doi.org/10.3390/ ijerph181910270

Academic Editors: Rejane C. Marques, José Garrofe Dórea and Rafael Junqueira Buralli

Received: 28 June 2021

Accepted: 23 September 2021

Published: 29 September 2021

Publisher's Note: MDPI stays neutral with regard to jurisdictional claims in published maps and institutional affiliations.

Copyright: (c) 2021 by the authors. Licensee MDPI, Basel, Switzerland. This article is an open access article distributed under the terms and conditions of the Creative Commons Attribution (CC BY) license (https:// creativecommons.org/licenses/by/ $4.0 /)$.

\begin{abstract}
There has been increasing evidence about mercury $(\mathrm{Hg})$ contamination in traditional populations from the Amazon Basin due to illegal gold mining. The most concerning health impact is neurotoxicity caused by $\mathrm{Hg}$ in its organic form: methylmercury ( $\mathrm{MeHg})$. However, the severity and extent of the neurotoxic effects resulting from chronic environmental exposure to $\mathrm{MeHg}$ are still unclear. We conducted a clinical-epidemiological study to evaluate the neurological impacts of chronic $\mathrm{MeHg}$ exposure in Munduruku indigenous people, focusing on somatosensory, motor, and cognitive abnormalities. All participants were subjected to a systemized neurological exam protocol, including Brief Cognitive Screening Battery (BCSB), verbal fluency test, and Stick Design Test. After the examination, hair samples were collected to determine $\mathrm{MeHg}$ levels. Data collection took place between 29 October and 9 November 2019, in three villages (Sawré Muybu, Poxo Muybu, and Sawré Aboy) from Sawré Muybu Indigenous Land, Southwest of Pará state. One hundred and ten individuals $>12$ years old were included, 58 of which were men (52.7\%), with an average age of 27.6 years (range from 12 to 72). Participants' median MeHg level was $7.4 \mu \mathrm{g} / \mathrm{g}$ (average: 8.7; S.D: 4.5; range: 2.0-22.8). In Sawré Aboy village, the median $\mathrm{MeHg}$ level was higher $(12.5 \mu \mathrm{g} / \mathrm{g})$ than in the others, showing a significant statistical exposure gradient (Kruskal-Wallis test with $p$-value $<0.001)$. Cerebellar ataxia was observed in two participants with MeHg levels of 11.68 and $15.68 \mu \mathrm{g} / \mathrm{g}$. Individuals with $\mathrm{MeHg}$ exposure level $\geq 10 \mu \mathrm{g} / \mathrm{g}$ presented around two-fold higher chances of cognitive deficits (RP: 2.2; CI 95\%: 1.13-4.26) in BCSB, and in the verbal fluency test (RP: 2.0; CI 95\%: 1.18-3.35). Furthermore, adolescents of 12 to 19 years presented three-fold higher chances of verbal development deficits, according to the fluency test (RP: 3.2; CI 95\%: 1.06-9.42), than individuals of 20 to 24 years. The worsened motor and cognitive functions are suggestive of neurotoxicity due to chronic $\mathrm{MeHg}$ exposure. In conclusion, we believe monitoring and follow-up measures are necessary for chronic mercury exposed vulnerable people, and a basic care protocol should be established for contaminated people in the Brazilian Unified Health System.
\end{abstract}

Keywords: mercury exposure; neurological abnormalities; indigenous people; Amazon; environmental impacts; illegal mining

\section{Introduction}

Methylmercury (MeHg) is a toxic organo-mercurial compound which acts systemically in the human body [1,2]. The intake dose, exposure duration, and frequency, in addition to the exposure route and age of the individual (or stage of development), are factors that 
determine the extent of damage caused by $\mathrm{MeHg}$ and which organs or systems are worst affected [3].

After the Minamata and Niigata disasters in Japan in the 1950s and 1960s, the international scientific community agreed that methylmercury's main target is the Central Nervous System (CNS) [4]. During that time, it was observed that adult individuals who regularly consumed contaminated fish presented neurological abnormalities such as paresthesia, ataxia, dysarthria, visual field alterations, and hearing impairments. In addition, these events showed that the prenatal period is the most vulnerable stage to the deleterious effects of MeHg. Many women who were exposed during pregnancy gave birth to children with severe congenital malformations and significant cognitive impairments [5-7]. Years later, the clinical manifestation caused by the exposure to high $\mathrm{MeHg}$ levels during adult life or pregnancy became known as Minamata Disease [8,9].

The MeHg intoxication episode in Iraq, in the early 1970s, was even more devastating than Japan's tragedy. Because it was an acute exposure episode, there were more than 6000 hospitalizations due to intoxication and hundreds of deaths in a short period of time $[10,11]$. In that time, the refinement of the spectrometry of atomic absorption technique for analyzing $\mathrm{Hg}$ in human tissue made laboratorial measurements more precise. Consequently, it was possible to establish a consistent relationship between the signs and symptoms presented by the exposed individuals and mercury concentration in exposure biomarkers (e.g., hair and blood) [6]. Based on scientific evidence, the World Health Organization established [4] that the neurological effects of MeHg exposure can be found in $5 \%$ of adult individuals who ingest 3 to $7 \mu$ g daily of $\mathrm{MeHg}$ per kilogram of body weight (kg bw). This daily intake dose corresponds to levels of $200 \mu \mathrm{g} / \mathrm{L}$ in blood or $50 \mu \mathrm{g} / \mathrm{g}$ in hair. However, these indexes are constantly revised, and some are updated as a result of new technologies and current research carried out in different parts of the world.

Since the 1990s, research conducted in the Amazon region identified adult individuals with neurological abnormalities probably associated with the consumption of contaminated fish. In those individuals, levels of methylmercury in hair samples varied between 10 and $20 \mu \mathrm{g} / \mathrm{g}$ [12-17]. Similar findings were reported in riparian populations in Bolivia and Suriname $[18,19]$.

It is worth noting that the peculiar characteristics of the Amazon's ecosystem and the social dynamics of its traditional populations may be responsible for the different thresholds for the onset of neurological effects. In that region, the majority of the mercury human exposure is due to artisanal small-scale gold mining (ASGM) [20]. ASGM causes the liberation of large quantities of $\mathrm{Hg}$ in the ecosystem and, at the same time, mobilizes natural Hg present in the soil. In addition to ASGM, the construction of hydroelectric plants and dams, deforestation, and fires also alter the $\mathrm{Hg}$ cycle in the region, increasing the risk of human contamination [20-24]. Moreover, the traditional people living there are considered to be among the largest consumers of fish in the world [25-27].

In the aquatic environment, the $\mathrm{Hg}$ released by the ASGM suffers methylation, mediated by microorganisms, transforming it into methylmercury (MeHg). Most of the toxicity attributed to $\mathrm{MeHg}$ is due to its biomagnification capacity in aquatic trophic chains and to the ability to overcome blood-brain and placenta barriers. Because fish consumption is the main protein source in many traditional populations in the Amazon, chronic exposure to high levels of mercury can cause various negative consequences and create health problems in local populations [20,28-32]. After intake of contaminated fish, almost all MeHg is quickly absorbed by the gastrointestinal tract. The absorbed $\mathrm{MeHg}$ forms a conjugate with the cysteine molecules present in the blood and, afterward, is distributed to virtually all human body tissue. When the MeHg reaches the CNS, it undergoes oxidation and tends to accumulate, leading to potentially irreversible cerebral tissue damage [33].

Experimental evidence shows that $\mathrm{MeHg}$ neurotoxicity is marked by an increase in oxidative stress, by the presence of mitochondrial lesions, by the release of excitatory amino acids, and by proteomic expression alterations, which can lead to cellular dysfunction and death [34-36]. Furthermore, the chronic exposure to high levels of $\mathrm{MeHg}$ has been 
associated with memory and learning deficits, motor function abnormalities, hearing loss, and a reduced visual field [3,20,37-42].

In the Amazon region, few clinical studies have correlated $\mathrm{MeHg}$ exposure levels with neurological symptoms [12-14,16,17]. Nevertheless, none of these studies included indigenous populations. Therefore, there is insufficient evidence about neurotoxicity concerning indigenous populations chronically exposed to MeHg in the Amazon Basin.

With the lack of evidence on this topic in mind, this study aimed to describe neurological clinical manifestations, focusing on somatosensory, motor, and cognitive abnormalities, in adults indigenous from three Munduruku villages in the Amazon Basin. The ultimate goal was to explore possible associations between neurological abnormalities with chronic methylmercury exposure.

\section{Materials and Methods}

\subsection{Study Design and Field Work}

We conducted a cross-sectional clinical-epidemiological study including indigenous people older than 12 years old living in three villages: Sawré Muybu (SM), Poxo Muybu (PM), and Sawré Aboy (SA), in the Sawré Muybu Indigenous Land (IL), located at Middle-Tapajós River, in the southwest region of Pará state, Brazilian Amazon.

Data collection occurred between 29 October and 9 November 2019, according to a multidisciplinary and inter-institutional study developed to clarify the consequences and assess the impacts of illegal mining in the Sawré Muybu IL. For additional information, see Basta et al. [43].

\subsection{Evaluated Population}

We performed a census in the three villages mentioned above, and all indigenous individuals aged 12 or older were invited to participate in the study. Therefore, probabilistic sampling methods were not used to select participants. A 15-year-old man from Sawré $M u y b u$ village, who had cerebral palsy, was excluded from the study.

\section{Fish Consumption Estimates}

Like the majority of the traditional groups living in the Amazon Basin, Munduruku people consume large quantities of fish. Recently, Vasconcellos et al. [44] carried out an investigation to estimate the fish consumption of the Munduruku indigenous people living in the study area and compared their findings with the acceptable levels proposed by the FAO/WHO [45] and by the U.S.EPA [46].

During one week, the authors collected 88 fish specimens representing 17 species and four trophic levels to analyze the total mercury $(\mathrm{THg})$ concentration in muscle tissue. They also developed an empirical method to estimate fish consumption from catch effort. The average daily fish consumption estimated for adult men was $216.75 \mathrm{~g}$, and for women of childbearing age was $168.58 \mathrm{~g}$. Considering that about $90-95 \%$ of total mercury species detected in fish samples is in the form of $\mathrm{MeHg}$ [47-49], we assume that all of the $\mathrm{Hg}$ detected in the fish samples is compounded by MeHg.

The average MeHg levels in samples of non-piscivorous fish $(\mathrm{n}=57)$ was $0.10 \mu \mathrm{g} / \mathrm{g}$ $(\mathrm{SD}=0.09)$ and the average for piscivorous fish $(\mathrm{n}=31)$ was $0.44 \mu \mathrm{g} / \mathrm{g}(\mathrm{SD}=0.34)$. The highest level of methylmercury in muscle tissue $(1.95 \mu \mathrm{g} / \mathrm{g})$ was observed in the Serrasalmus rhombeus (also known as piranha preta in Portuguese), a fish not only located at the top of the food chain, but also highly appreciated and regularly consumed by the Munduruku [44].

Moreover, the authors devised four scenarios to estimate the MeHg exposure, considering the fish consumption from catch effort: (i) in the rainy season; (ii) in the dry season; (iii) based on the weighted average of medium mercury levels detected in piscivorous and non-piscivorous species; and (iv) based on the $95^{\text {th }}$ percentile of mercury concentrations in piscivorous and non-piscivorous species (1.42 and $0.29 \mu \mathrm{g} / \mathrm{g}$, respectively).

According to the authors, scenario (iii) most closely matches the local reality, in which the estimates of $\mathrm{MeHg}$ ingestion for Munduruku adult men ranged from 1.84- to 
8.28-fold above the safe daily methylmercury intake recommended by FAO/WHO [45] and U.S.EPA [46], respectively. The estimates ranged from 3.17- to 7.29-fold above the FAO/WHO [45] and U.S.EPA [46], respectively, for women of childbearing age.

Summarizing, the studied Munduruku villages are at severe risk of harm due to the ingestion of MeHg-contaminated fish.

\subsection{Neurological Examination}

All participants were submitted to a systemized neurological examination protocol, specifically developed for this research, to make the evaluation feasible in the adverse conditions of the fieldwork in the villages. The evaluations were conducted by neurologists (BDP, BHR, and RAAO) familiar with clinical neurological semiology and duly trained to apply the protocol and use the examining instruments.

The explanations about the clinical procedures for the neurological exam were verbally presented to the participants in Brazilian Portuguese. When necessary, for indigenous individuals that had difficulties with Portuguese, an indigenous translator (indigenous health agents, teachers, or chiefs) from the village would assist.

\subsubsection{Static Balance and Walking Evaluation}

The evaluation of static balance and walking was performed by visual inspection. Participants were asked to remain in an orthostatic position to perform the Romberg test, with eyes open and closed, sequentially. Then, participants were asked to walk towards the examiner.

\subsubsection{Cranial Nerve Examination}

The following parameters were evaluated: visual campimetry by confrontation, pupil reflex and external ocular motricity, facial motricity and symmetry, facial sensibility, palate elevation, gag reflex and tongue motricity.

\subsubsection{Sensory Testing}

The following instruments were used to evaluate the respective somatosensory modalities:

(a) Sharp nickel-plated pin (Bacchi ${ }^{\circledR}$ number 29): mechanical nociceptive perception.

(b) Sorri Bauru esthesiometer/Von Frey 10g monofilament: tactile sensitivity.

(c) Dry cotton wad: dynamic tactile sensitivity.

(d) $128 \mathrm{~Hz}$ diapason: tactile vibration sensitivity and thermic sensitivity to cold [50].

The sensitivity was tested in upper and lower limbs at three distinct points for each sensory modality, in the proximal and distal segments. The sensitivity was classified as normal (0) or abnormal (1) depending on the abnormality occurrence in at least one parameter.

For the clinical diagnosis of distal symmetric polyneuropathy, criteria from the American Academy of Neurology were used, which consider the occurrence of distal sensory deficits, in addition to the clinical signs of neuropathy, defined as the presence of abnormalities in at least one somatic sensory domain and/or alterations in the ankle jerk reflex [51].

\subsubsection{Motor Function}

Muscular strength was evaluated through maneuvers against resistance in all four limbs, on proximal and distal segments. Muscular hypertonia and bradykinesia were evaluated through passive mobilization of the four members, through finger tapping maneuvers, facial expression mimicking, and spontaneous mobilization. Coordination was evaluated through finger to nose, heel to knee, and diadochokinesis (ability to make alternating quick movements) tests. The deep osteotendinous ankle jerk reflex was tested with the Babinski hammer, according to the Hallett [52] myotatic reflex score. Toe amyotrophy was investigated through inspection. 


\subsubsection{Cognitive Evaluation}

All individuals were submitted to a cognitive evaluation by the authors (BDP, BHR and RAAO), immediately after the neurological exam, as part of the evaluation protocol.

An indigenous translator from the village was present in the interviews to help with the communication with indigenous individuals who had difficulties with Portuguese.

The Brief Cognitive Screening Battery (BCSB) [53], the verbal fluency test in the animal category [54], and the stick design test [55] were used as instruments of cognitive evaluation. These instruments were selected given their appropriateness for populations with low levels of education and for the easy application in adverse conditions in the field.

\section{Brief Cognitive Screening Battery (BCSB)}

The BCSB is an instrument developed by the Cognitive and Behavior Neurology Group of the Hospital das Clinicas of the Medical School of the Universidade de São Paulo [53], which entails naming and remembering 10 drawings of simple and known objects in black and white presented in a single picture. This instrument evaluates, in sequence, the following domains: (a) visual perception and naming, (b) incidental memory, (c) immediate memory, (d) learning, (e) verbal fluency test (described below), (f) 5 min belated memory, and $\mathrm{g}$ ) recognition.

The following cutoffs were used in the tests to evaluate the domains' normality: immediate memory $(\geq 5)$, learning $(\geq 7)$, verbal fluency $(\geq 9)$, and delayed recall $(\geq 6)$. Alteration in at least one of these domains was considered a criterion for abnormality for the BCSB, finally classified as: (0) normal or (1) abnormal.

\section{Verbal Fluency Test in the Animal Category}

To evaluate verbal fluency, participants were asked to name as many animals as they could in one minute. The individuals received the following instructions: "you must say the animal names you remember, as quickly as possible. Any animal will do, four-legged, fish, birds, the more you say, the better". The cutoff for verbal fluency test normality was $\geq 9$. This test was applied as part of the BCSB, as an interference factor.

\section{Stick Design Test}

To evaluate logical thinking, participants were asked to reproduce geometric shapes, presented on a sheet of paper one after the other, with matches. The number of sides, the image and stick orientation in each of the four images were criteria considered for the test score, which varies from zero to 12 . Scores $\geq 10$ were considered the cutoff for normality and classified as normal (0) or abnormal (1).

\section{4. $\mathrm{MeHg}$ Exposure Biomarker}

According to the guidance published by the World Health Organization [56], and described by other authors $[57,58]$, hair samples are considered the best biomarker of the $\mathrm{MeHg}$ human exposure, because almost all $\mathrm{Hg}$ detected in this kind of biological matrix is in the $\mathrm{MeHg}$ form. In addition, because the main $\mathrm{Hg}$ exposure route observed in the studied population is the consumption of $\mathrm{Hg}$-contaminated fish, and almost all $\mathrm{Hg}$ present in the fish muscle is in the MeHg form, hair samples were used as its exposure biomarker [47-49]. Therefore, we assume for this study that all $\mathrm{Hg}$ present in hair samples is MeHg.

The hair's samples were collected from the occipital region, with the aid of stainlesssteel dissection scissors, from all participants. The samples were stored in individually identified paper envelopes and sent for total mercury concentration ( $\mathrm{THg}$ ) analysis in the Toxicology Laboratory in the Environmental Section of the Instituto Evandro Chagas (IEC).

In the laboratory, before starting the analyses, hair samples were repeatedly washed with Extran detergent (Merck KGaA, Darmstadt, Germany) to remove any exogenous contamination. After drying, the samples were finely homogenized in glass flasks before weighing. This methodology comprises chemical opening, wet digestion, and subsequent 
reduction with $\mathrm{SnCl}_{2}$ to quantify total $\mathrm{Hg}$ in a Cold Vapor Atomic Absorption Spectrometer (CVAAS).

The protocols for Quality Assurance (QA)/Quality Control (QC) included the following parameters: (i) a method blank; (ii) a 6-point calibration curve (concentration ranging from 0.4 to $4 \mathrm{ng} / \mathrm{g}$ ); (iii) the Human Hair Certified Reference Material (IAEA-86), whose average recovery rate was $101 \%(\mathrm{n}=8$, recovery ranging from 83.4 to $106.6 \%)$ from the International Atomic Energy Agency; and (iv) the relative standard deviation (RSD) of $8.32 \%$. Sample replicates $(\mathrm{n}=10)$, whose RSD was $2.49 \%$, were also randomly selected. The detection and quantification limits (LOD/LOQ) obtained were $0.0083 \mathrm{ng} / \mathrm{mg}$ and 0.027 $\mathrm{ng} / \mathrm{mg}$, respectively.

For further detail on hair sample analysis, see Basta et al. [43].

\subsection{Statistical Analysis}

A descriptive analysis of the participants was undertaken according to sociodemographic variables: sex (female / male), age (12 to $19 ; 20$ to 24,25 to 29 , and $\geq 30$ years old) and village of residence (Sawré Muybu, Poxo Muybu, and Sawré Aboy), in contrast to the evaluated neurological parameters.

To estimate the prevalence of exposure, in the numerator we included participants older than 12 who presented with methylmercury levels $\geq 10.0 \mu \mathrm{g} / \mathrm{g}$. In the denominator, the population sampled for the study in the same age group was considered. The prevalence was presented for the three villages under study: Sawré Muybu, Poxo Muybu, and Sawré Aboy.

The main neurological abnormalities detected in the clinical exam were compared between two groups, according to the participants' level of methylmercury exposure: $\geq 10.0$ vs. $<10.0 \mu \mathrm{g} / \mathrm{g}$.

Because mercury levels do not show a normal distribution, the Kruskal-Wallis nonparametric test was used to evaluate differences in methylmercury levels in all comparisons that showed measures of central tendency (medians). The difference in proportion between variables was evaluated using Pearson's chi-squared test.

We used a Poisson regression model with robust variance to estimate the association between alterations observed in the BCSB and the verbal fluency test in the animal category with independent variables: (i) methylmercury exposure level ( $<10.0 \mathrm{vs.} \geq 10.0 \mu \mathrm{g} / \mathrm{g}$ ); age (12 to $19 ; 20$ to 24,25 to 29 , and $\geq 30$ years old); and (ii) sex (female vs. male). Prevalence Ratio (PR), with the respective confidence interval of $95 \%$, was used as an association measure.

Variables with a $p$-value $<0.20$ in the simple analysis were selected and included in the multiple model. Variables that presented significance levels of $5 \%(p<0.05)$ remained in the final model. The data was analyzed with the statistical software SPSS version 9.0 (Chicago, IL, USA).

\section{Results}

During the field work, 110 indigenous individuals were evaluated, 50 of whom were from the Sawré Muybu (SM) village, 37 from the Poxo Muybu (PM) village, and 23 from the Sawré Aboy (SA) village. Fifty-eight were men (52.7\%) and 52 were women (47.3\%). The participants age ranged from 12 to 72 years (average: 27.6 years; standard deviation: 13.7). The participants' distribution, according to age group, was heterogenous in the studied villages. There was a predominance of adolescents (12 to 19 years) in PM and SA villages, with $16(43.2 \%)$ and $11(47.8 \%)$ participants, respectively, compared to nine $(18.0 \%)$ participants in the SM village. In contrast, in Sawré Muybu there was the highest concentration of young adults between 25 and 29 years of age $(26.0 \%)(p=0.032)$ (Table 1$)$. 
Table 1. Sociodemographic variables, hair-methylmercury level groups, somatosensory and motor functions, and cognitive alterations, according to the village of residence. Sawré Muybu Indigenous Land, Pará state, Brazilian Amazon, 2019.

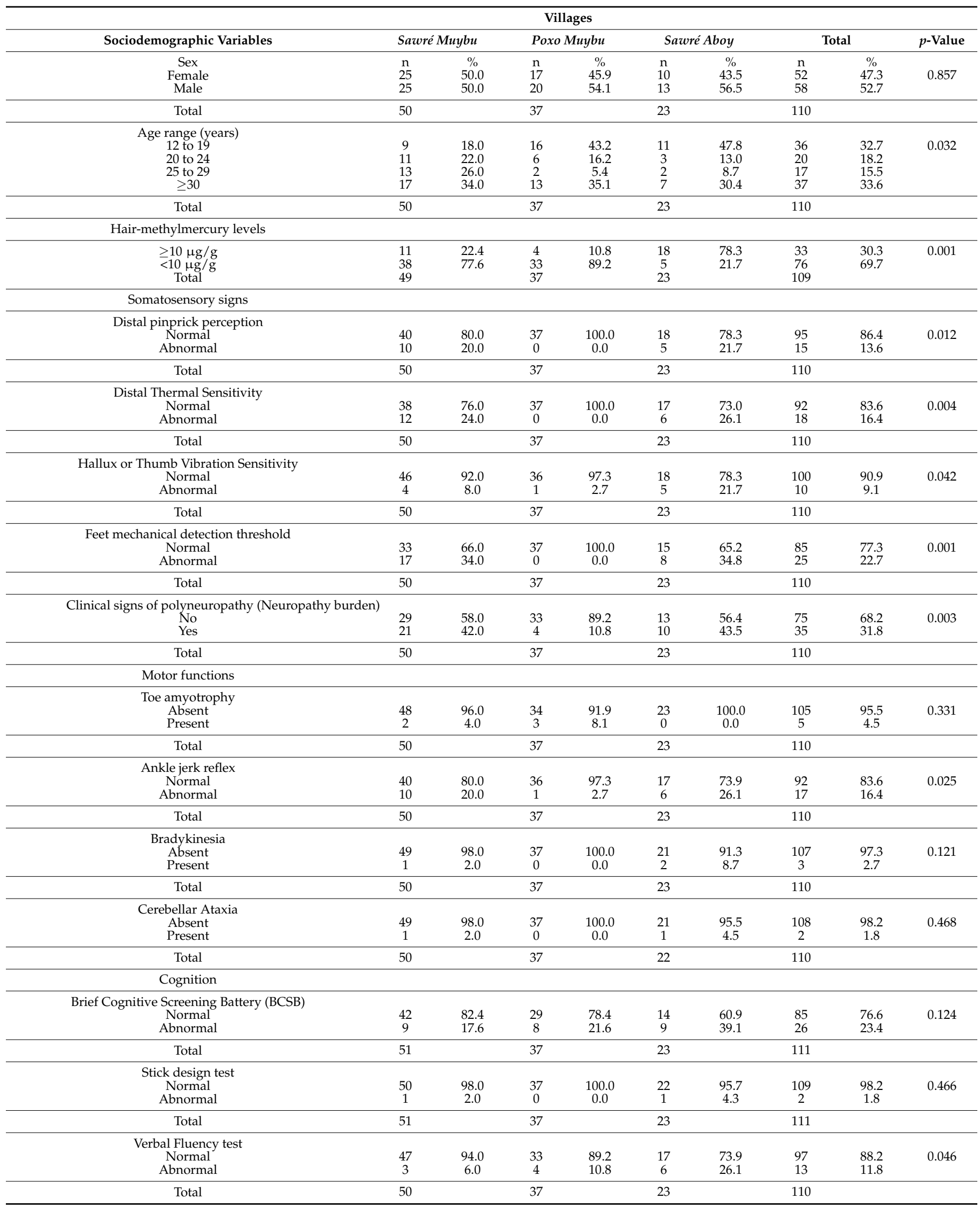




\subsection{Overall Data by Village}

No participant showed static balance, walking, or cranial nerve function alterations. There were significant somatosensory alterations in the SM and SA villages in contrast to PM, represented here by the distal pinprick perception $(p=0.012)$, distal thermal sensitivity $(p=0.004)$, hallux or thumb vibration sensitivity (pallesthesia) $(p=0.042)$, and feet mechanical detection threshold $(p=-0.001)$. Clinical signs of polyneuropathy were detected in 21 (42.0\%) participants from Sawré Muybu village and 10 (43.5\%) participants from Sawré Aboy village, revealing a significant superior prevalence compared to Poxo Muybu village, where only $4(10.8 \%)$ participants were affected $(p=0.003)$ (Table 1$)$.

Two $(1.9 \%)$ indigenous people presented with alterations in cerebellar motor alterations ataxy, one from SM and one from SA villages, and three $(2.8 \%)$ presented with bradykinesia, two of which were from SA and one from SM village, with no significant differences in the distribution between the villages. No signs of hypertonia or rigidity were detected in participants (Table 1 ).

Five $(4.5 \%)$ participants were diagnosed with toe amyotrophy, three of which were from PM village and two from SM village $(p$-value $=0.331)$. There were no recorded cases of amyotrophy in SA.

The absence of ankle jerk reflex was detected in $10(20 \%)$ and six (26.1\%) participants from SM and SA village, respectively, and was more prevalent than in PM village, where it was observed in only one (2.7\%) individual $(p=0.025)$ (Table 1$)$.

Regarding cognitive manifestations, there were BCSB abnormalities in $39.1 \%$ $(\mathrm{n}=9)$ of participants from SA village, whereas in SM and PM the alterations affected $17.6 \%$ $(\mathrm{n}=9)$ and $21.6 \%(\mathrm{n}=8)$ of participants, respectively $(p=0.089)$ (Table 1$)$.

Impairments in the verbal fluency test were detected in $21.6 \%(n=6)$ of participants from SA village. In contrast, in PM and SM, the verbal fluency affected $10.8 \%(n=4)$ and $6.0 \%(n=3)$ of participants, respectively $(p=0.046)($ Table 1$)$.

Alterations in the stick design test were observed in only one $(2.0 \%)$ individual from SM village and in one (4.3\%) individual from SA $(p=0.466)$.

\subsection{Neurological Abnormalities According to MeHg Exposure Levels}

In general, the median MeHg level in participants was $7.4 \mu \mathrm{g} / \mathrm{g}$ (average: 8.7; standard deviation: 4.5; range from 2.0 to 22.8). In Poxo Muybu village, the median $\mathrm{MeHg}$ level in participants was $7.3 \mu \mathrm{g} / \mathrm{g}$ (average: 7.3; standard deviation: 2.3; range from 2.3 to 12.9). In Sawré Muybu village, the median MeHg level in participants was $6.5 \mu \mathrm{g} / \mathrm{g}$ (average: 7.4; standard deviation: 4.2; range from 2.0 to 22.1). Finally, in Sawré Aboy village, the median $\mathrm{MeHg}$ level in participants was $12.5 \mu \mathrm{g} / \mathrm{g}$ (average: 13.5; standard deviation: 4.6; range from 4.8 to 22.8), showing a significant statistical exposure gradient (Kruskal-Wallis Test with $p$-value $<0.001$ ).

The MeHg exposure prevalence over $10 \mu \mathrm{g} / \mathrm{g}$ also varied according to the studied villages, $78.3 \%$ of which from SA, $22.4 \%$ from SM, and 10.8\% from PM ( $p$-value $=0.001$ ) (Table 1). However, there were no significant differences in MeHg exposure considering age group and sex (Table 2).

\subsubsection{Somatic Sensitivity (Somatosensory)}

Alterations in distal pinprick perception were found in 14.5 and $12.1 \%$ of participants in the exposure groups of $<10$ and $\geq 10 \mu \mathrm{g} / \mathrm{g} \mathrm{MeHg}$, respectively ( $p$-value $=0.743$ ) (Table 2 ).

Distal thermal sensitivity alterations were observed in $14.5 \%$ of participants of exposure group of $<10 \mu \mathrm{g} / \mathrm{g}$, in comparison to $21.2 \%$ in the group of $\geq 10 \mu \mathrm{g} / \mathrm{g} \mathrm{MeHg}$ $(p$-value $=0.384)($ Table 2$)$.

Hallux or thumb vibration sensitivity alterations were seen in $6.6 \%$ of participants in the exposure group of $<10 \mu \mathrm{g} / \mathrm{g}$, in contrast to $15.2 \%$ in the exposure group of $\geq 10 \mu \mathrm{g} / \mathrm{g}$ $\operatorname{MeHg}(p=0.154)$ (Table 2). 
Table 2. Sociodemographic variables, somatosensory and motor functions, and cognition signs, according to hair-MeHg levels (<10 vs. $\geq 10 \mu \mathrm{g} / \mathrm{g}$ ), Sawré Muybu Indigenous Land, Pará state, Brazilian Amazon, 2019.

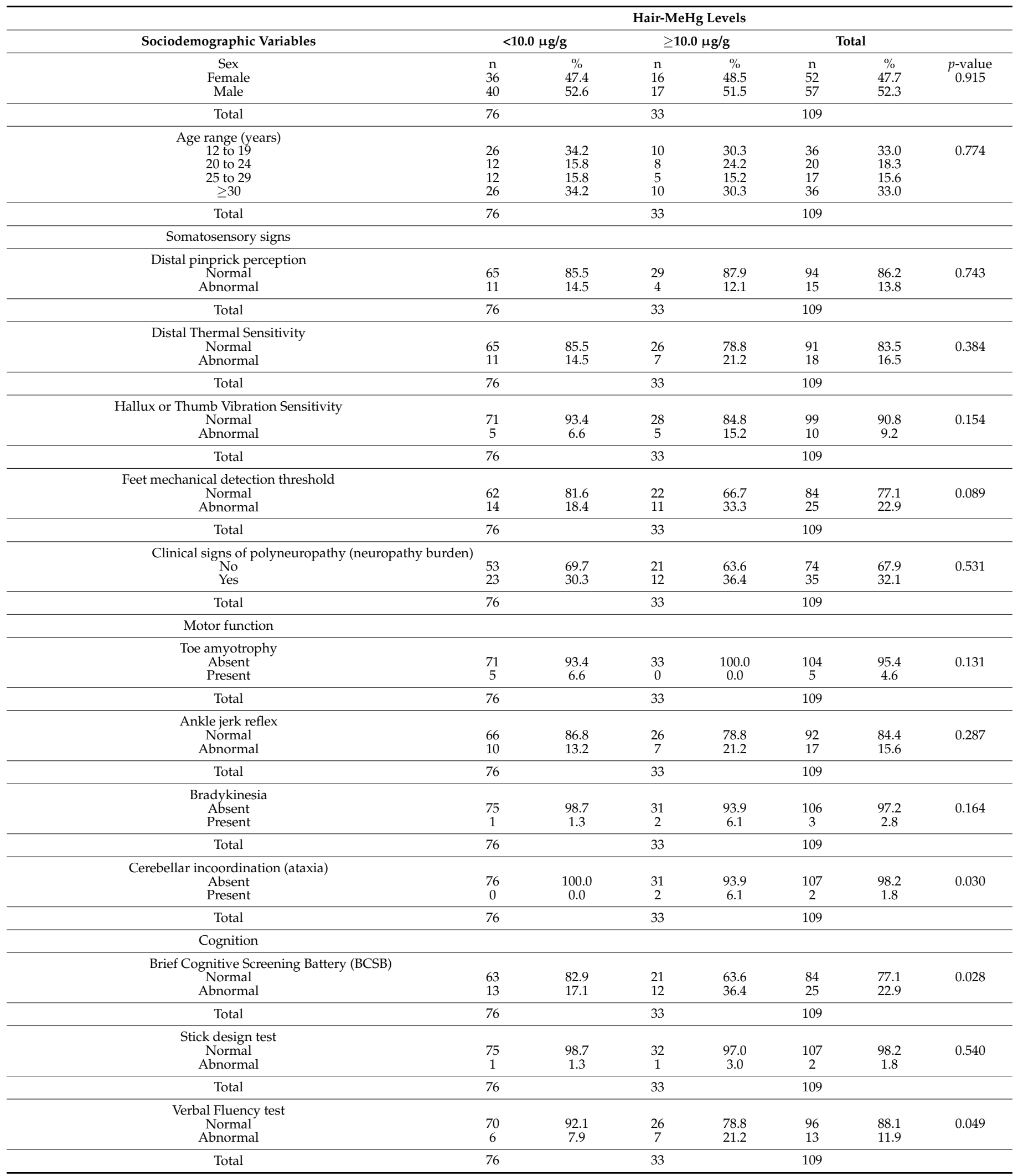


Feet mechanical detection threshold (hypoesthesia) alterations were detected in $18.4 \%$ of participants in the exposure group of $<10 \mu \mathrm{g} / \mathrm{g}$, in contrast to $33.3 \%$ in the exposure group of $\geq 10 \mu \mathrm{g} / \mathrm{g} \mathrm{MeHg}(p=0.089)$ (Table 2$)$.

Finally, the clinical signs of polyneuropathy, indicative of distal symmetric polyneuropathy, were similar in the groups, and were reported in $30.3 \%$ of indigenous individuals with the exposure $<10 \mu \mathrm{g} / \mathrm{g}$ and in $36.4 \%$ of those with exposure $\geq 10 \mu \mathrm{g} / \mathrm{g} \mathrm{MeHg}$ $(p=0.531)$ (Table 2).

\subsubsection{Motor Function}

Toe amyotrophy was recorded in five individuals (6.6\%) in SM village. The ankle jerk reflex absence appeared in 13.2 and $21.2 \%$ of indigenous individuals exposed to levels of $\mathrm{MeHg}<10 \mu \mathrm{g} / \mathrm{g}$ and $\geq 10.0 \mu \mathrm{g} / \mathrm{g}(p=0.287)$, respectively (Table 2$)$.

The occurrence of bradykinesia was detected in three indigenous individuals: an individual with a methylmercury exposure level of $9.08 \mu \mathrm{g} / \mathrm{g}$, and in two other participants with exposure levels of 11.68 and $20.18 \mu \mathrm{g} / \mathrm{g}(p=0.164)$ (Table 2).

Cerebellar motor incoordination (ataxia) was observed in two participants with exposure levels of 11.68 and $15.86 \mu \mathrm{g} / \mathrm{g} \mathrm{MeHg}(p=0.030)$.

\subsubsection{Cognitive Alterations}

According to the BCSB, cognitive alterations were observed in $17.1 \%$ of indigenous individuals with $\mathrm{MeHg}$ exposure levels of $<10 \mu \mathrm{g} / \mathrm{g}$, in contrast with $36.4 \%$ of those with an exposure of $\geq 10 \mu \mathrm{g} / \mathrm{g}(p=0.028)$ (Table 2$)$.

Moreover, the participants with MeHg exposure levels of $<10 \mu \mathrm{g} / \mathrm{g}$ showed $7.9 \%$ of alteration in the verbal fluency test in the animal category, whereas $21.2 \%$ of participants with $\mathrm{MeHg}$ exposure levels of $\geq 10 \mu \mathrm{g} / \mathrm{g}$ presented alterations ( $p=0.049$ ) (Table 2$)$.

Two individuals $(1.8 \%$ of the total) presented with alterations in the stick design test, one with a MeHg exposure level of $9.67 \mu \mathrm{g} / \mathrm{g}$, and the other with $22.75 \mu \mathrm{g} / \mathrm{g}$ (Table 2). It is worth noting that the recorded exposure level in the latter was the highest in the studied population.

3.2.4. Main Findings Considering the Neurological Abnormalities, According to MeHg Exposure Levels

Table 3 summarizes the main results, highlighting neurological clinical variables that presented an association with hair-MeHg levels $(\geq 10 \mu \mathrm{g} / \mathrm{g})$. Considering the presence of somatosensory signs, abnormalities in the feet mechanical detection threshold affected $33.3 \%$ of the participants with $\mathrm{MeHg}$ levels above $10 \mu \mathrm{g} / \mathrm{g}$, in contrast to $18.4 \%$ of the participants with MeHg levels below $10 \mu \mathrm{g} / \mathrm{g}$. Regarding motor function, only two cases of ataxia were detected. However, both were observed in participants with MeHg levels above $10 \mu \mathrm{g} / \mathrm{g}$.

Regarding the cognition abilities, 36.4\% of the participants with MeHg levels above $10 \mu \mathrm{g} / \mathrm{g}$ presented abnormalities in the Brief Cognitive Screening Battery (BCSB). In contrast, $17.1 \%$ of the participants with $\mathrm{MeHg}$ levels below $10 \mu \mathrm{g} / \mathrm{g}$ showed abnormalities in the BCSB. Finally, concerning the verbal fluency test, $21.2 \%$ of the participants with $\mathrm{MeHg}$ levels above $10 \mu \mathrm{g} / \mathrm{g}$ presented abnormalities, in contrast to $7.9 \%$ of the participants with MeHg levels below $10 \mu \mathrm{g} / \mathrm{g}$ (Table 3).

\subsubsection{Poisson's Regression Model Findings, Considering Cognition Abilities of the Participants}

Poisson's regression modeling revealed that participants with $\mathrm{MeHg}$ exposure levels $\geq 10 \mu \mathrm{g} / \mathrm{g}$ showed approximately two-fold higher chances of suffering from cognitive deficits in the BCSB (PR: 2.2; CI 95\%: 1.13-4.26) and the verbal fluency test (PR: 2.0; CI 95\%: 1.18-3.35). Furthermore, the final model showed that 12 to 19 year old adolescents presented with around a three-fold chance of developing deficits in the verbal fluency test (PR: 3.2; CI 95\%: 1.06-9.42), compared to 20 to 24 year old young adults, even controlling for the effect of mercury exposure level and sex (Table 4). 
Table 3. Summary of the main results highlighting clinical variables that presented an association $(p$-value $<0.10)$ with hair-MeHg levels ( $\geq 10 \mu \mathrm{g} / \mathrm{g})$, Sawré Muybu Indigenous Land, Pará state, Brazilian Amazon, 2019.

\begin{tabular}{|c|c|c|c|c|c|c|c|}
\hline \multirow{3}{*}{$\begin{array}{c}\text { Clinical Variables } \\
\text { Somatosensory Signs }\end{array}$} & \multicolumn{6}{|c|}{ Hair-MeHg Levels } & \multirow[b]{3}{*}{$p$-Value } \\
\hline & \multicolumn{2}{|c|}{$<10.0 \mu \mathrm{g} / \mathrm{g}$} & \multicolumn{2}{|c|}{$\geq 10.0 \mu \mathrm{g} / \mathrm{g}$} & \multicolumn{2}{|c|}{ Total } & \\
\hline & $\mathbf{N}$ & $\%$ & $\mathbf{n}$ & $\%$ & $\mathbf{n}$ & $\%$ & \\
\hline \multicolumn{8}{|c|}{ Feet mechanical detection threshold } \\
\hline Normal & 62 & 81.6 & 22 & 66.7 & 84 & 77.1 & 0.089 \\
\hline Abnormal & 14 & 18.4 & 11 & 33.3 & 25 & 22.9 & \\
\hline Total & 76 & & 33 & & 109 & & \\
\hline \multicolumn{8}{|l|}{ Motor function } \\
\hline \multicolumn{8}{|c|}{ Cerebellar incoordination (ataxia) } \\
\hline Absent & 76 & 100.0 & 31 & 93.9 & 107 & 98.2 & 0.030 \\
\hline Present & 0 & 0.0 & 2 & 6.1 & 2 & 1.8 & \\
\hline Total & 76 & & 33 & & 109 & & \\
\hline \multicolumn{8}{|l|}{ Cognition } \\
\hline \multicolumn{8}{|c|}{ Brief Cognitive Screening Battery (BCSB) } \\
\hline Normal & 63 & 82.9 & 21 & 63.6 & 84 & 77.1 & 0.028 \\
\hline Abnormal & 13 & 17.1 & 12 & 36.4 & 25 & 22.9 & \\
\hline Total & 76 & & 33 & & 109 & & \\
\hline \multicolumn{8}{|l|}{ Verbal Fluency test } \\
\hline Normal & 70 & 92.1 & 26 & 78.8 & 96 & 88.1 & 0.049 \\
\hline Abnormal & 6 & 7.9 & 7 & 21.2 & 13 & 11.9 & \\
\hline Total & 76 & & 33 & & 109 & & \\
\hline
\end{tabular}

Table 4. Logistic regression model (crude and adjusted) of prevalence ratios (PR) in the Brief Cognitive Screening Battery (BCSB) and verbal fluency test, Sawré Muybu Indigenous Land, Pará state, Brazilian Amazon, 2019.

\begin{tabular}{|c|c|c|c|c|}
\hline \multicolumn{5}{|c|}{ Cognitive Screening Brief Battery } \\
\hline Variables & PR Crude (CI 95\%) & $p$-Value & PR Adjusted (CI 95\%) & $p$-Value \\
\hline $\begin{array}{l}\text { Hair-MeHg level } \\
<10 \mu \mathrm{g} / \mathrm{g} \\
\geq 10 \mu \mathrm{g} / \mathrm{g}\end{array}$ & $\begin{array}{c}1.0 \\
2.1(1.08-4.15) \\
\end{array}$ & 0.027 & $\begin{array}{c}1.0 \\
2.2(1.13-4.26) \\
\end{array}$ & 0.028 \\
\hline $\begin{array}{c}\text { Age range (years) } \\
20 \text { to } 24 \\
12 \text { to } 19 \\
25 \text { to } 29 \\
\geq 30\end{array}$ & $\begin{array}{c}1.0 \\
1.3(0.38-4.47) \\
1.7(0.51-5.46) \\
2.2(0.65-7.61)\end{array}$ & $\begin{array}{l}0.681 \\
0.399 \\
0.204\end{array}$ & $\begin{array}{c}1.0 \\
1.5(0.44-4.80) \\
1.9(0.60-6.05) \\
2.4(0.74-7.82)\end{array}$ & $\begin{array}{l}0.424 \\
0.280 \\
0.144\end{array}$ \\
\hline $\begin{array}{l}\text { Sex } \\
\text { Female } \\
\text { Male }\end{array}$ & $\begin{array}{c}1.0 \\
1.1(0.57-2.29) \\
\end{array}$ & 0.71 & $\begin{array}{c}1.0 \\
1.2(0.61-2.32) \\
\end{array}$ & 0.492 \\
\hline \multicolumn{5}{|l|}{ Verbal Fluency Test } \\
\hline Variables & PR Crude (CI 95\%) & $p$-Value & PR Adjusted (CI 95\%) & $p$-Value \\
\hline $\begin{array}{c}\text { Hair-MeHg level } \\
\quad<10 \mu \mathrm{g} / \mathrm{g} \\
\geq 10 \mu \mathrm{g} / \mathrm{g}\end{array}$ & $\begin{array}{c}1.0 \\
1.9(1.07-3.38) \\
\end{array}$ & 0.03 & $\begin{array}{c}1.0 \\
2.0(1.18-3.35) \\
\end{array}$ & 0.010 \\
\hline $\begin{array}{c}\text { Age range (years) } \\
20 \text { to } 24 \\
12 \text { to } 19 \\
25 \text { to } 29 \\
\geq 30\end{array}$ & $\begin{array}{c}1.0 \\
3.0(0.98-8.95) \\
0.8(0.15-4.16) \\
1.8(0.56-5.81)\end{array}$ & $\begin{array}{l}0.054 \\
0.775 \\
0.324\end{array}$ & $\begin{array}{c}1.0 \\
3.2(1.06-9.42) \\
0.9(0.16-4.64) \\
2.0(0.63-6.46)\end{array}$ & $\begin{array}{l}0.039 \\
0.871 \\
0.239\end{array}$ \\
\hline $\begin{array}{l}\text { Sex } \\
\text { Female } \\
\text { Male }\end{array}$ & $\begin{array}{c}1.0 \\
0.6(0.31-1.05)\end{array}$ & 0.071 & $\begin{array}{c}1.0 \\
0.6(0.34-1.11)\end{array}$ & 0.109 \\
\hline
\end{tabular}

\section{Discussion}

This exploratory clinical-epidemiological study was the first to produce evidence about the neurotoxic effects of consuming contaminated fish by $\mathrm{MeHg}$ in adults from the Munduruku indigenous population. The findings were produced with a comparative 
analysis of systemized neurological evaluation data in contrast to hair-MeHg concentration, used as a biomarker of chronic mercury exposure.

There is strong evidence substantiating MeHg neurotoxicity in experimental models and humans [33-35,42]. The neurological manifestations, classically described after the acute intoxication by $\mathrm{MeHg}$, in Minamata Bay, Japan, in 1953, are characterized by somatosensory dysfunctions, ataxia, incoordination, tremors, and visual and neuropsychiatric symptoms [8,9]. A study conducted by Yorifuji et al. [59] also confirms that the neurological manifestations are due to the methylmercury contamination and are irrefutable evidence that the toxicity produced by this chemical element lasts for decades.

However, in the context of chronic environmental exposure, there is still no solid causal connection between the neurological dysfunction and toxicity due to methylmercury, as highlighted by Puty et al. [60], who conducted a systematic review of this theme. Despite the relevance of this systematic review in consolidating the scientific knowledge, it is essential to emphasize that this study included only six papers, and most of these (i.e., four) do not provide data on mercury concentration in exposure biomarkers. Consequently, we can conclude that almost all selected research in that review presumptively reported human mercury exposure.

Nonetheless, when we focus only on research conducted in the Amazon region, we observe that most of these studies indicate that exposure to $\mathrm{MeHg}$ may be responsible for neurological alterations in adult individuals [13-19]. In this region, the mercury levels detected in exposure biomarkers can be up to 10-fold higher than the limits recommended by health agencies $[45,46]$. The main neurological alterations include cognitive, visual, motor, somatosensory, and behavioral changes [13-19,61-68].

The impact of gold mining on human mercury exposure has been described by some studies that compared exposed populations to control groups (for example, populations living in areas with no previous history of mining activities) [16,69-72]. These studies indicate that hair mercury levels detected in areas impacted by mining activities are considerably higher than those observed in control groups. Even considering the natural mercury available in the Amazon soil, these findings reinforce the hypothesis that the region's primary source of human mercury contamination is mining activities.

In the present study, somatosensory, motor, and cognitive abnormalities were researched in indigenous adults from the Munduruku people who live in three villages, located in the region of Middle-Tapajos River. The participants with higher mercury exposure levels ( $\geq 10 \mu \mathrm{g} / \mathrm{g} \mathrm{MeHg})$ presented the highest prevalence of cognitive impairment, according to the BCSB and the verbal fluency test results, and cerebellar incoordination, both indicating CNS dysfunctions. Distal somatosensory deficits and verbal fluency reduction were also reported. These alterations were more frequent in Sawré Aboy village, where there was the highest mercury exposure, compared to Sawré Muybu and Poxo Muybu villages. Again, this finding strengthens the hypothesis that the primary source of mercury exposure in the studied villages is mining activities.

\subsection{Somatosensory Abnormalities}

In the group with the highest $\mathrm{MeHg}$ exposure $(\geq 10 \mu \mathrm{g} / \mathrm{g})$, there was also a higher prevalence of abnormalities in the feet mechanical detection threshold, in comparison to the group with lower exposure (33.3\% vs. $18.4 \%, p=0.089$ ). There was a slim predominance of temperature and vibrant hypoesthesia in participants with methylmercury exposure higher than $10 \mu \mathrm{g} / \mathrm{g}$ (Table 2), however, there was no statistical significance. Even considering different methodological approaches, our findings revealed the highest somatosensory abnormalities in comparison to the study conducted by Khoury et al. [63,64], in which there was a decrease in hypoesthesia, tactile sensitivity, and pain, in $11.5 \%(\mathrm{n}=9)$ of riparian residents in Barreiras and 13.3\% $(\mathrm{n}=4)$ of residents in São Luiz do Tapajós, areas in the Pará State, in the Amazon Basin, equally affected by mining activities. In turn, the somatosensory alterations reported here were higher than those observed in a region known as Furo do Maracujá ( $\mathrm{n}=1 ; 2.0 \%$ ), an area considered free of mercury exposure, 
and therefore classified as a control area by the authors $[63,64]$. However, due to the small number of participants, the differences highlighted in the study were not statistically significant.

The comparison by village revealed a significantly lower prevalence of somatosensory abnormalities in Poxo Muybu village, in contrast to Sawré Aboy and Sawré Muybu villages (Table 1). The difference in occurrence of alterations was revealed in all sensory modalities investigated, either in the tactile superficial sensory $(p=0.001)$, temperature sensitivity $(p=0.004)$ and pain sensitivity (nociceptive) $(p=0.012)$, and hallux and thumb deep sensitivity (vibration) $(p=0.042)$. In the same manner, Poxo Muybu was the village where lower frequencies were reported of ankle jerk reflex alterations $(p=0.025)$ and clinical signs of polyneuropathy $(p=0.003)$.

These findings provide evidence of the toxic effects of methylmercury, because Poxo $M u y b u$ village recorded the lowest proportion of participants with exposure levels above $10 \mathrm{\mu g} / \mathrm{g} \mathrm{MeHg}(10.8 \%)$, whereas in Sawré Muybu and Sawré Aboy villages the exposure prevalence was approximately two to eight times higher, reaching $22.4 \%$ and $78.3 \%$ of participants, respectively.

However, although there is a tendency of major abnormalities in distal thermal sensory, deep vibration, and tactile superficial sensitivity, the magnitude of the somatosensory alterations observed in the comparative analysis by village was not confirmed, according to the methylmercury exposure groups. In part, this contradiction can be explained by the reduced size of our sample. However, it is important to note that the average methylmercury levels in all participants were high (average: $8.7 \mu \mathrm{g} / \mathrm{g}$; range from 2.0 to 22.8), which makes it difficult for more robust analysis, because we did not have a control group, without mercury exposure, for comparison.

It is important to note that distal somatosensory alterations and clinical signs of polyneuropathy are indicative of peripheral nervous system (PNS) dysfunctions that can be induced by several clinical conditions in addition to mercury contamination. The presence of chronic alcoholism, diabetes mellitus, and sexually transmittable diseases was actively researched in our study population, via interview, blood glucose level testing, or rapid HIV, syphilis, and viral hepatitis testing, with no positive cases identified (for further detail see Basta et al. [43]). Nutritional deficits, especially B12 deficiency, are also potential causes of polyneuropathy and somatosensory abnormalities. However, these nutritional deficiencies were not researched and may add a degree of bias to our findings. It must also be noted that the use of a hair sample as a biomarker for mercury exposure may not be adequate, especially in the adult population, for detecting the neuropathy cases [33]. It is possible that the clinical signs of neuropathy detected here may have begun prior to our research for reasons not evaluated.

However, it cannot by overlooked that the clinical signs of polyneuropathy, diagnosed in approximately one-third of all participants, were more frequent in Sawré Muybu and Sawré Aboy villages, where the highest levels of $\mathrm{MeHg}$ exposure were detected.

Similar to the results reported in this study, Takaoka et al. [73] compared an indigenous population in Canada who lived in a region affected by chloralkali industrial waste, with two populations in Japan, one exposed to mercury in Minamata Bay and the other in a nonaffected area (control). The authors reported complaints and neurological abnormalities as more prevalent. In addition, somatosensory signs were more evident in the Canadian indigenous group and in the Japanese group exposed to mercury compared to the control group.

In another study conducted in Japan, Takaoka et al. [38] presented a detailed description of somatosensory symptoms that included perioral numbness, hands and feet numbness, cramps, difficulty in hearing, smelling, and tasting, difficulty in buttoning shirts, and difficulty executing fine tasks with fingers. The authors reported that the symptoms were more frequently observed in individuals who ate fish with $\mathrm{Hg}$ concentrations higher than levels considered to be safe. They concluded that their findings indicated that the ef- 
fects of Minamata disease were observed almost 50 years after Chisso Corporation stopped polluting water with methylmercury, in 1968.

In our study, the presence of distal hypoesthesia and clinical signs of polyneuropathy were respectively observed in $33.3 \%$ and $36.4 \%$ in the group with the highest mercury exposure $(\geq 10 \mu \mathrm{g} / \mathrm{g})$. These findings were similar to those reported by Yorifuri et al. [59], who showed somatosensory abnormalities in 25 and $58 \%$ of participants with mercury exposure higher than $10 \mu \mathrm{g} / \mathrm{g}$ in the contaminated areas of Minamata and Goshonoura, Japan, respectively.

In the Amazon region, Khoury et al. [63,64] described somatosensory complaints of numbness of the extremities in 11.5 and $13.3 \%$ of participants of riparian communities in two areas of the state of Pará, which are under the influence of mining and, therefore, exposed to mercury.

Due to communication difficulties arising because Munduruku people express themselves in their native language and do not speak fluent Portuguese, in this study, we exclusively evaluated clinical signs through a patterned neurological exam. In contrast to other authors $[8,63,64,73]$, we opted not to include any complaints or symptoms reported by participants in the collected data.

\subsection{Motor Functions Abnormalities}

Cerebellar signs were only detected in two indigenous individuals, who presented with methylmercury exposure higher than $10 \mu \mathrm{g} / \mathrm{g}$. Similarly, Takaoka et al. [39] described alterations in the finger to nose test, which indicates cerebellar dysfunction, in 21 and $47 \%$ of two groups with high mercury exposure, in Japan. Cerebellar symptomatology was also described in other empirical studies $[15,39,59]$ and in revision papers $[8,60,74]$. In turn, Khoury et al. $[63,64]$ described altered walking in participants with high mercury exposure levels compared to the control group. However, there was no mention of cerebellar signs.

Bradykinesia or slowness of movement were identified in three indigenous individuals in our study. They did not present rigidity or tremors. Bradykinesia, usually found in rigid-hypokinetic or parkinsonian syndromes, is not part of the classical manifestation of acute mercury intoxication, as described in Japan [8,59].

Nonetheless, experimental evidence associates mercury toxicity with dopaminergic depletion in the CNS [40] and establishes a possible correlation with parkinsonian and neurodegenerative diseases [75], even considering the latency period after mercury exposure [76]. In this sense, we propose two possibilities: (i) bradykinesia is an isolated symptom, or (ii) it may be a part of an incomplete parkinsonian syndrome falling within the spectrum of neurological manifestations of mercury contamination in this indigenous population from the Amazon. To clarify this question, we suggest a longitudinal evaluation in those populations at risk of chronic methylmercury exposure, with a priority for those cases with bradykinesia and other neurological signs and symptoms. In this manner, we believe that it will be possible to broaden the knowledge on this subject, which is surrounded by controversy and uncertainty.

\subsection{Cognitive Abnormalities}

Cognitive evaluation in individuals with a low education level is a challenging task, especially in indigenous populations who live in diverse sociocultural and environmental contexts. Language and communication barriers, in addition to the lack of appropriate evaluation instruments, were some of the difficulties experienced by our team. When choosing the evaluation instruments, we selected those that allowed us to overcome communication barriers, had references to the local population's everyday elements, and were easily applicable in the context of the fieldwork in the villages. The BCSB domains used in this study allowed the evaluation of immediate memory, verbal fluency, and belated memory. It is essential to consider years of schooling, a factor significantly related to some cognitive tests [77] but not related to the ability to solve everyday problems, as highlighted in our evaluation. 
Despite the limitations, the proportion of higher impairment rates in the BCSB in participants with high methylmercury exposure levels $(\geq 10 \mu \mathrm{g} / \mathrm{g})$ was more than two-fold (36.4\%) those observed (17.1\%) in participants with lower exposure levels $(<10 \mu \mathrm{g} / \mathrm{g})$ $(p=0.028)$. Similarly, Yorifuji et al. [59], in an enquiry that analyzed the Minamata population in the early $1970 \mathrm{~s}$, revealed significantly more frequent intelligence limitations (RP 5.2, 95\% CI 3.7-7.3) and behavior alterations (RP 4.4, 95\% CI 2.9-6.7) in the group exposed to methylmercury, in contrast to the control group.

It is worth noting that the neuropsychiatric manifestations, including irritability, depression, social isolation, aggressiveness, or even psychotic cases ("mad hatter disease") were described in association with acute mercury intoxication [74]. In a bibliography review, Jackson [74] concluded that methylmercury poisoning causes chronic neurological illness, mainly due to direct neural lesions in the brain, particularly involving the cerebral cortex and granular cells, and reinforces the importance of detailed clinical evaluation to assess the extent of neurological deficits in chronically exposed populations.

In the Amazon scenario, the neuropsychiatric manifestations are more frequently associated with occupational exposure and are reported in miners who burn amalgam to separate mercury from gold and inhale mercury's toxic vapors. Considering environmental exposure through the consumption of contaminated fish, which is manifested chronically and insidiously, there are few studies that report cognitive deficiencies and neuropsychiatric manifestations. Khoury et al. [63,64] analyzed depression complaints and symptoms such as fear, sadness, and insomnia in the riparian population in two areas in the Amazon with different mercury exposure levels. Despite the effort made in the analysis, the authors found that there were no statistical differences between the exposed and control groups.

In our study, the detected memory and verbal fluency impairments indicate cognitive deficits are more frequent in the indigenous people with the highest methylmercury levels ( $\geq 10 \mu \mathrm{g} / \mathrm{g}$ ). Moreover, cognitive impairment was more frequent in 12- to 19-year-old adolescents. Because chronic methylmercury exposure may cause cognitive, motor, and somatosensory losses, this finding requires caution in interpretation and warrants deeper analysis. The investigated communities, who live in a highly contaminated environment, at present, in addition to the future generations (women of childbearing age and babies), are under permanent threat. Our findings emphasize the need for new studies that deepen cognitive and psychiatric evaluation to generate even more robust evidence about the $\mathrm{MeHg}$ toxicity in vulnerable populations, and demand interventions from the authorities and social leadership.

\subsection{Limitations}

Bradykinesia, temperature sensitivity, tactile and deep distal alterations, and clinical signs of polyneuropathy were more prevalent in the group with methylmercury exposure higher than $10 \mu \mathrm{g} / \mathrm{g}$. However, due to the limited size of our sample, the differences were not statistically significant. The broadening of the study to other areas with the inclusion of a greater number of participants may result in more conclusive data.

In this study, we prioritized the evaluation of somatosensory abnormalities aimed at detecting PNS lesions. Somatosensory alterations from CNS lesions were described in anatomo-clinical studies [39] and clinical trials [8]. The two-point discrimination test, graphesthesia, and stereognosis have the potential to evaluate central somatosensory dysfunctions and should also be considered in future studies.

The absence of a control group with low environmental MeHg exposure, which would allow comparisons, was also a limiting factor in our approach. In the preparatory phase of the study, we expected that Poxo Muybu village, which is farther from the mining zones, would be a control group for comparison. However, like the other villages, Poxo Muybu also presented high average levels of $\mathrm{MeHg}$ exposure (average: $7.3 \mu \mathrm{g} / \mathrm{g}$; range from 2.3 to 12.9), above the safe levels according to international health agencies $[45,46]$. Therefore, it was not possible to have a control group. 
It is also important to consider that the reference levels of mercury exposure vary between international health agencies, and do not necessarily reflect biological security parameters. The safety limits recommended are based on daily or weekly maximum intake parameters of $\mathrm{MeHg}$. The intake criteria have a strong relationship with $\mathrm{MeHg}$ levels detected in blood and hair. Therefore, $\mathrm{FAO} / \mathrm{WHO}$ [45] recommends maximum intake doses of $1.6 \mu \mathrm{g} / \mathrm{kg}$ (body weight)/week for more sensitive groups such as women of childbearing age and pregnant women, and $3.2 \mu \mathrm{g} / \mathrm{kg}$ bw/week for the general population. Thus, the reference intake limit doses considered to be safe, for those still not reported to have poisonous effects in human beings, correspond to mercury levels of 2.3 and $4.5 \mu \mathrm{g} / \mathrm{g}$ in hair samples, respectively [45].

Although our results may show promise in revealing higher cognitive deficits in participants with the highest methylmercury exposure levels, the BCSB has not yet been validated for use in traditional Amazonian populations. The use of simplified and validated instruments for evaluation of cognition in populations chronically exposed to mercury and ethnically differentiated can produce new evidence to consolidate the knowledge on this topic. Tools such as the mini-mental state examination [78], previously used in Amazonian populations [77], appear to be equally promising, and mainly associated with the BCSB.

\section{Conclusions}

The present study produced evidence concerning the association between motor and cognitive impairments in the CNS with chronic MeHg exposure among the Munduruku indigenous adults. The majority of people who suffered from neurological abnormalities presented MeHg exposure levels above $10 \mu \mathrm{g} / \mathrm{g}$.

Somatosensory abnormalities reported in the villages where the highest methylmercury exposures were registered also indicate toxicity signs in the PNS. However, the differences reported between the two exposure groups were not statistically significant. Due to the limited sample size, we believe it is necessary to conduct broader studies to deepen the knowledge about the neurotoxic effects of methylmercury in the traditional populations living in the Amazon Basin, and particularly indigenous populations.

In conclusion, despite its limitations, this study indicates that neurotoxicity due to chronic environmental methylmercury exposure in the Munduruku indigenous population provides evidence of the long-lasting persistent environmental impacts in the Amazon [20-24]. The context revealed here highlights the risk looming over the present and future generations, who represent a substantial social, ethnic, and culturally diverse community, and should be considered and treated as the country's most significant wealth.

Finally, we believe monitoring and follow-up measures are necessary for the vulnerable populations chronically exposed to methylmercury who live in the Amazon basin. Moreover, we consider it essential to establish a basic care protocol for contaminated people in the Brazilian Unified Health System (SUS) with the support of specialists.

Author Contributions: Proposal design, study design and methodology, R.A.A.d.O., D.C.d.A. and P.C.B. Fieldwork data collection, R.A.A.d.O., B.D.P. and B.H.R.; writing-original draft preparation, R.A.A.d.O. and P.C.B.; writing-review and editing, R.A.A.d.O., D.C.d.A., B.D.P., B.H.R., A.C.S.d.V. and P.C.B.; supervision, obtaining resources and project management, P.C.B. All authors have read and agreed to the published version of the manuscript.

Funding: This research was funded by the Vice-Presidency of Environment, Care and Health Promotion (VPAAPS) of Fundação Oswaldo Cruz (Fiocruz) through Decentralized Execution of Resources Document No. 175/2018, Process: 25000.209221/2018-18, signed between the Fiocruz and the Special Secretariat for Indigenous Health, both under the Ministry of Health. The non-governmental organization WWF-Brazil offered financial support to disseminate the results of the research.

Institutional Review Board Statement: The study was conducted in accordance with the guidelines of the Declaration of Helsinki and was approved by the Research Ethics Committee of the National School of Public Health at Fiocruz (REC/ENSP) and the Brazilian National Research Ethics Commission of the National Health Council (CONEP/CNS), CAAE: 65671517.1.0000.5240, with Opinion No. 2.262.686 favorable to its performance. In compliance with Convention No. 169 of the International Labor 
Organization (ILO), the study began with a pre-study consultation, carried out in August 2019, during a visit to the villages, in which the author $\mathrm{PCB}$, and local indigenous leaders participated. At the time, the study objectives were presented and discussed (https: / www.youtube.com $/$ watch? $\mathrm{v}=$ oFEYEGxNmns\&t=704s, accessed on 20 September 2019). After answering questions and approval of the proposal by the communities, we received support from the coordination of the Special Indigenous Sanitary District of the Tapajós River through the multidisciplinary indigenous health team to carry out the study. In addition, the interviews and data collection started only after the participants had their questions answered and formal consent was given via the Informed Consent Form (ICF) by the children's guardians.

Informed Consent Statement: Informed consent was obtained from all subjects involved in the study. Written informed consent was obtained from the patients to publish this paper.

Data Availability Statement: Data sharing not applicable.

Acknowledgments: On behalf of chiefs Juarez Saw, Jairo Saw, and Valdemar Poxo, and the leader Alessandra Korap, we thank the Munduruku people for the trust placed in our team and the support in carrying out the research. On behalf of Rio Tapajós Indigenous Special Sanitary District, we thank the coordination Cleidiane C.R. Santos and the nurses Alan Marcelo Simon and Lygia Catarina de Oliveira. We also thank to Marcelo de Oliveira Lima, Iracina Maura de Jesus and João Paulo Goes Pereira who performed the mercury laboratory analysis. We also thank Marcelo Oliveira-da-Costa from World-Wide Fund for Nature (WWF-Brazil) for technical and financial support for this scientific communication.

Conflicts of Interest: The authors declare no conflict of interest. The funders had no role in the design of the study; in the collection, analyses, or interpretation of data; in the writing of the manuscript, or in the decision to publish the results.

\section{References}

1. Hong, Y.S.; Kim, Y.M.; Lee, K.E. Methylmercury exposure and health effects. J. Prev. Med. Public Health 2012, 45, 353. [CrossRef]

2. Mergler, D.; Anderson, H.A.; Chan, L.H.M.; Mahaffey, K.R.; Murray, M.; Sakamoto, M.; Stern, A.H. Methylmercury exposure and health effects in humans: A worldwide concern. AMBIO J. Hum. Environ. 2007, 36, 3-11. [CrossRef]

3. Díez, S. Human health effects of methylmercury exposure. Rev. Environ. Cont. Toxicol. 2008, 198, 111-132.

4. World Health Organization. Environmental Health Criteria 1. Mercury; World Health Organization: Geneva, Switzerland, 1976.

5. World Health Organization. Mercury: Environmental Aspects-Environmental Health Criteria 86; World Health Organization: Geneva, Switzerland, 1989.

6. World Health Organization. IPCS Environmental Health Criteria 101: Methylmercury. International Programme of Chemical Safety; World Health Organization: Geneva, Switzerland, 1990.

7. National Research Council (US). Committee on the Toxicological Effects of Methylmercury. Toxicological Effects of Methylmercury; National Academies Press: Washington, DC, USA, 2000.

8. Ekino, S.; Susa, M.; Ninomiya, T.; Imamura, K.; Kitamura, T. Minamata disease revisited: An update on the acute and chronic manifestations of methyl mercury poisoning. J. Neurol. Sci. 2007, 262, 131-144. [CrossRef] [PubMed]

9. Sakamoto, M.; Tatsuta, N.; Izumo, K.; Phan, P.T.; Vu, L.D.; Yamamoto, M.; Nakamura, M.; Nakai, K.; Murata, K. Health impacts and biomarkers of prenatal exposure to methylmercury: Lessons from Minamata, Japan. Toxics 2018, 6, 45. [CrossRef]

10. Bakir, F.; Damluji, S.F.; Amin-Zaki, L.; Murtadha, M.; Khalidi, A.; Al-Rawi, N.Y.; Tikriti, S.; Dhahir, H.I.; Clarkson, T.W.; Smith, J.C.; et al. Methylmercury poisoning in Iraq. Science 1973, 181, 230-241. [CrossRef]

11. Bakir, F.; Rustam, H.; Tikriti, S.; Al-Damluji, S.F.; Shihristani, H. Clinical and epidemiological aspects of methylmercury poisoning. Postgrad. Med. J. 1980, 56, 1-10. [CrossRef] [PubMed]

12. Lebel, J.; Mergler, D.; Lucotte, M.; Amorim, M.; Dolbec, J.; Miranda, D.; Arantes, G.; Rheault, I.; Pichet, P. Evidence of early nervous system dysfunction in Amazonian populations exposed to low-levels of methylmercury. Neurotoxicology 1996, 17, 157-167. [PubMed]

13. Lebel, J.; Mergler, D.; Branches, F.; Lucotte, M.; Amorim, M.; Larribe, F.; Dolbec, J. Neurotoxic effects of low-level methylmercury contamination in the Amazonian Basin. Environ. Res. 1998, 79, 20-32. [CrossRef] [PubMed]

14. Dolbec, J.; Mergler, D.; Passos, C.J.S.; De Morais, S.S.; Lebel, J. Methylmercury exposure affects motor performance of a riverine population of the Tapajos river, Brazilian Amazon. Int. Arch. Occup. Environ. Health 2000, 73, 195-203. [CrossRef] [PubMed]

15. Harada, M.; Nakanishi, J.; Yasoda, E.; Maria da Conceicâo, N.P.; Oikawa, T.; de Assis Guimarâes, G.; da silva Cardoso, B.; Kizaki, T.; Ohno, H. Mercury pollution in the Tapajos River basin, Amazon: Mercury level of head hair and health effects. Environ. Int. 2001, 27, 285-290. [CrossRef]

16. Khoury, E.D.T.; Souza, G.D.S.; da Costa, C.A.; de Araújo, A.A.K.; de Oliveira, C.S.B.; Silveira, L.C.D.L.; Pinheiro, M.D.C.N. Somatosensory psychophysical losses in inhabitants of riverside communities of the Tapajós River Basin, Amazon, Brazil: Exposure to methylmercury is possibly involved. PLoS ONE 2015, 10, e0144625. [CrossRef] [PubMed] 
17. Lacerda, E.M.D.C.B.; Souza, G.D.S.; Cortes, M.I.T.; Rodrigues, A.R.; Pinheiro, M.C.N.; Silveira, L.C.D.L.; Ventura, D.F. Comparison of Visual Functions of Two Amazonian Populations: Possible Consequences of Different Mercury Exposure. Front. Neurosci. 2020, 13, 1428. [CrossRef] [PubMed]

18. Benefice, E.; Luna-Monrroy, S.; Lopez-Rodriguez, R. Fishing activity, health characteristics and mercury exposure of Amerindian women living alongside the Beni River (Amazonian Bolivia). Int. J. Hyg. Environ. Health 2010, 213, 458-464. [CrossRef] [PubMed]

19. Peplow, D.; Augustine, S. Neurological abnormalities in a mercury exposed population among indigenous Wayana in Southeast Suriname. Environ. Sci. Process. Impacts 2014, 16, 2415-2422. [CrossRef] [PubMed]

20. Crespo-López, M.E.; Augusto-Oliveira, M.; Lopes-Araújo, A.; Santos-Sacramento, L.; Takeda, P.Y.; Macchi, B.M.; do Nascimento, J.L.M.; Maia, C.S.F.; Lima, R.R.; Arrifano, G.P. Mercury: What can be learn from the Amazon? Environ. Int. 2021, 146, 106223. [CrossRef] [PubMed]

21. Azevedo, L.S.; Pestana, I.A.; Almeida, M.G.; da Costa Nery, A.F.; Bastos, W.R.; Souza, C.M.M. Mercury biomagnification in an ichthyic food chain of an amazon floodplain lake (Puruzinho Lake): Influence of seasonality and food chain modeling. Ecotoxicol. Environ. Saf. 2021, 207, 111249. [CrossRef] [PubMed]

22. Siqueira-Gay, J.; Soares-Filho, B.; Sanchez, L.E.; Oviedo, A.; Sonter, L.J. Proposed Legislation to Mine Brazil's Indigenous Lands Will Threaten Amazon Forests and Their Valuable Ecosystem Services. One Earth 2020, 3, 356-362. [CrossRef] [PubMed]

23. Lino, A.S.; Kasper, D.; Guida, Y.S.; Thomaz, J.R.; Malm, O. Total and methyl mercury distribution in water, sediment, plankton and fish along the Tapajós River basin in the Brazilian Amazon. Chemosphere 2019, 235, 690-700. [CrossRef] [PubMed]

24. Arrifano, G.P.; Martín-Doimeadios, R.C.; Jiménez-Moreno, M.; Ramírez-Mateos, V.; da Silva, N.F.; Souza-Monteiro, J.R.; AugustoOliveira, M.; Paraense, R.S.; Macchi, B.M.; do Nascimento, J.L.; et al. Large-scale projects in the amazon and human exposure to mercury: The case-study of the Tucuruí Dam. Ecotoxicol. Environ. Saf. 2018, 147, 299-305. [CrossRef]

25. Cerdeira, R.G.P.; Ruffino, M.L.; Isaac, V.J. Consumo de Pescado e Outros Alimentos Pela População Ribeirinha do Lago Grande de Monte Alegre, PA-Brasil. Acta Amaz. 1997, 27, 213-227. [CrossRef]

26. Santos, G.M.D.; Santos, A.C.M.D. Sustentabilidade da pesca na Amazônia. Estud. Av. 2005, 19, 165-182. [CrossRef]

27. Arruda, M.C.F.D. Avaliação dos Indicadores da Política de Pesca do Programa Zona Franca Verde: Perspectivas Econômicas e Ambientais. Master's Thesis, Programa de Pós-Graduação em Engenharia de Produção, Universidade Federal do Amazonas (UFAM), Manaus, Brasil, 2017. Available online: https:// tede.ufam.edu.br/handle/tede/6068 (accessed on 19 June 2021).

28. Santos-Lima, C.D.; Mourão, D.S.; Carvalho, C.F.; Souza-Marques, B.; Vega, C.M.; Gonçalves, R.A.; Argollo, N.; Menezes-Filho, J.A.; Abreu, N.; Hacon, S.S. Neuropsychological Effects of Mercury Exposure in Children and Adolescents of the Amazon Region, Brazil. Neurotoxicology 2020, 79, 48-57. [CrossRef]

29. Basu, N.; Horvat, M.; Evers, D.C.; Zastenskaya, I.; Weihe, P.; Tempowski, J. A State-of-the-Science Review of Mercury Biomarkers in Human Populations Worldwide between 2000 and 2018. Environ. Health Perspect. 2018, 126, 106001. [CrossRef] [PubMed]

30. Sharma, S.; Baligar, R.S.; Singh, H.B.; Butcher, R.J. Reaction of a metallamacrocycle leading to a mercury(II)...palladium(II)...mercury (II) interaction. Angew. Chem. Int. Ed. Engl. 2009, 48, 1987-1990. [CrossRef] [PubMed]

31. Bauch, S.C.; Birkenbach, A.M.; Pattanayak, S.K.; Sills, E.O. Public health impacts of ecosystem change in the Brazilian Amazon. Proc. Natl. Acad. Sci. USA 2015, 112, 7414-7419. [CrossRef] [PubMed]

32. Berzas Nevado, J.J.; Rodríguez Martín-Doimeadios, R.C.; Guzmán Bernardo, F.J.; Jiménez Moreno, M.; Herculano, A.M.; do Nascimento, J.L.; Crespo-López, M.E. Mercury in the Tapajós River basin, Brazilian Amazon: A review. Environ. Int. 2010, 36 , 593-608. [CrossRef] [PubMed]

33. Karri, V.; Schuhmacher, M.; Kumar, V. Heavy metals ( $\mathrm{Pb}, \mathrm{Cd}$, As and MeHg) as risk factors for cognitive dysfunction: A general review of metal mixture mechanism in brain. Environ. Toxicol. Pharmacol. 2016, 48, 203-213. [CrossRef] [PubMed]

34. Oliveira, C.S.; Segatto, A.L.A.; Nogara, P.A.; Piccoli, B.C.; Loreto, É.L.S.; Aschner, M.; Rocha, J.B.T. Transcriptomic and Proteomic Tools in the Study of Hg Toxicity: What Is Missing? Front. Genet. 2020, 11, 425. [CrossRef] [PubMed]

35. Birdsall, R.E.; Kiley, M.P.; Segu, Z.M.; Palmer, C.D.; Madera, M.; Gump, B.B.; MacKenzie, J.A.; Parsons, P.J.; Mechref, Y.; Novotny, M.V.; et al. Effects of lead and mercury on the blood proteome of children. J. Proteome Res. 2010, 9, 4443-4453. [CrossRef]

36. Santos-Sacramento, L.; Arrifano, G.P.; Lopes-Araújo, A.; Augusto-Oliveira, M.; Albuquerque-Santos, R.; Takeda, P.Y.; SouzaMonteiro, J.R.; Macchi, B.M.; do Nascimento, J.L.M.; Lima, R.R.; et al. Human neurotoxicity of mercury in the Amazon: A scoping review with insights and critical considerations. Ecotoxicol. Environ. Saf. 2021, 208, 111686. [CrossRef]

37. Day, J.J.; Reed, M.N.; Newland, M.C. Neuromotor deficits and mercury concentrations in rats exposed to methyl mercury and fish oil. Neurotoxicol. Teratol. 2005, 27, 629-641. [CrossRef] [PubMed]

38. Takaoka, S.; Fujino, T.; Kawakami, Y.; Shigeoka, S.I.; Yorifuji, T. Survey of the Extent of the Persisting Effects of Methylmercury Pollution on the Inhabitants around the Shiranui Sea, Japan. Toxics 2019, 6, 39. [CrossRef] [PubMed]

39. Takaoka, S.; Kawakami, Y.; Fujino, T.; Oh-ishi, F.; Motokura, F.; Kumagai, Y.; Miyaoka, T. Somatosensory disturbance by methylmercury exposure. Environ. Res. 2008, 107, 6-19. [CrossRef]

40. Shao, Y.; Chan, H.M. Effects of methylmercury on dopamine release in MN9D neuronal cells. Toxicol. Mech. Methods 2015, 25, 637-644. [CrossRef] [PubMed]

41. Farias, L.A.; Fávaro, D.I.T.; Pessoa, A.; Aguiar, J.P.L.; Yuyama, L.K.O. Mercury and methylmercury concentration assessment in children's hair from Manaus, Amazonas state, Brazil. Acta Amaz. 2012, 42, 279-286. [CrossRef]

42. Crespo-López, M.E.; Herculano, A.M.; Corvelo, T.C.; Do Nascimento, J.L. Mercurio y neurotoxicidad [Mercury and neurotoxicity]. Rev. Neurol. 2005, 40, 441-447. [PubMed] 
43. Basta, P.C.; Viana, P.V.S.; Vasconcellos, A.C.S.; Périssé, A.R.S.; Hofer, C.B.; Paiva, N.S.; Kempton, J.W.; Ciampi de Andrade, D.; Oliveira, R.A.A.; Achatz, R.W.; et al. Mercury exposure in Munduruku indigenous communities from Brazilian Amazon: Methodological background and an overview of the principal results. Int. J. Environ. Res. Public Health 2021, 18, 9222. [CrossRef] [PubMed]

44. Vasconcellos, A.C.S.; Hallwass, G.; Bezerra, J.G.; Aciole, A.N.S.; Meneses, H.N.M.; Lima, M.O.; Jesus, I.M.; Hacon, S.S.; Basta, P.C. Health Risk Assessment of Mercury Exposure from Fish Consumption in Munduruku Indigenous Communities in the Brazilian Amazon. Int. J. Environ. Res. Public Health 2021, 18, 7940. [CrossRef] [PubMed]

45. FAO/WHO. Evaluation of certain food additives and contaminants: Sixty-first report of the Joint FAO/WHO Expert Committee on Food Additives. In Proceedings of the Joint FAO/WHO Expert Committee on Food Additives (JECFA), Rome, Italy, 10-19 June 2003.

46. U.S. EPA. Reference Dose for Methylmercury; U.S. Environmental Protection Agency: Washington, DC, USA, 2000.

47. Marrugo-Negrete, J.; Verbel, J.O.; Ceballos, E.L.; Benitez, L.N. Total mercury and methylmercury concentrations in fish from the Mojana region of Colombia. Environ. Geochem. Health 2008, 30, 21-30. [CrossRef] [PubMed]

48. Kehrig, H.; Malm, O.; Akagi, H.; Guimarães, J.R.; Torres, J.P.M. Methylmercury in fish and hair samples from the Balbina Reservoir, Brazilian Amazon. Environ. Res. 1998, 77, 84-90. [CrossRef] [PubMed]

49. Souza-Araujo, J.; Giarrizzo, T.; Lima, M.O.; Souza, M.B.G. Mercury and methyl mercury in fishes from Bacaja River (Brazilian Amazon): Evidence for bioaccumulation and biomagnification. J. Fish Biol. 2016, 89, 249-263. [CrossRef] [PubMed]

50. Campbell, W.W. DeJong's the Neurological Examination, 6th ed.; Lippincott Williams \$ Wilkins: Philadelphia, PA, USA, 2005.

51. England, J.D.; Gronseth, G.S.; Franklin, G.; Miller, R.G.; Asbury, A.K.; Carter, G.T.; Cohen, J.A.; Fisher, M.A.; Howard, J.F.; Kinsella, L.J.; et al. Distal symmetric polyneuropathy: A definition for clinical research: Report of the American Academy of Neurology, the American Association of Electrodiagnostic Medicine, and the American Academy of Physical Medicine and Rehabilitation. Neurology 2005, 64, 199-207. [CrossRef] [PubMed]

52. Hallett, M. NINDS Myotactic reflex scale. Neurology 1993, 43, 2723. [CrossRef] [PubMed]

53. Brucki, S.M.; Nitrini, R. Subjective memory impairment in a rural population with low education in the Amazon rainforest: An exploratory study. Int. Psychogeriatr. 2009, 21, 164-171. [CrossRef]

54. Brucki, S.M.; Malheiros, S.M.; Okamoto, I.H.; Bertolucci, P.H. Dados normativos para o teste de fluência verbal categoria animais em nosso meio [Normative data on the verbal fluency test in the animal category in our milieu]. Arq. Neuropsiquiatr. 1997, 55, 56-61. [CrossRef]

55. Baiyewu, O.; Unverzagt, F.W.; Lane, K.A.; Gureje, O.; Ogunniyi, A.; Musick, B.; Gao, S.; Hall, K.S.; Hendrie, H.C. The Stick Design test: A new measure of visuoconstructional ability. J. Int. Neuropsychol. Soc. 2005, 11, 598-605. [CrossRef] [PubMed]

56. World Health Organization (WHO). Guidance for Identifying Populations at Risk from Mercury Exposure; Mercury Publications: Geneva, Switerzeland, 2008; Available online: https:/ / wedocs.unep.org/.../IdentifyingPopnatRiskExposuretoMercury_2008 (accessed on 22 June 2021).

57. Berglund, M.; Lind, B.; Björnberg, K.A.; Palm, B.; Einarsson, O.; Vahter, M. Inter-individual variations of human mercury exposure biomarkers: A cross-sectional assessment. Environ. Health 2005, 4, 20. [CrossRef]

58. Clarkson, T.W.; Magos, L. The toxicology of mercury and its chemical compounds. Crit. Rev. Toxicol. 2006, 36, 609-662. [CrossRef] [PubMed]

59. Yorifuji, T.; Tsuda, T.; Takao, S.; Suzuki, E.; Harada, M. Total mercury content in hair and neurologic signs: Historic data from Minamata. Epidemiology 2009, 20, 188-193. [CrossRef]

60. Puty, B.; Leão, L.K.R.; Crespo-Lopez, M.E.; Almeida, A.P.C.P.S.C.; Fagundes, N.C.F.; Maia, L.C.; Lima, R.R. Association between methylmercury environmental exposure and neurological disorders: A systematic review. J. Trace Elem. Med. Biol. 2019, 52, 100-110. [CrossRef]

61. Fillion, M.; Lemire, M.; Philibert, A.; Frenette, B.; Weiler, H.A.; Deguire, J.R.; Guimaraes, J.R.; Larribe, F.; Barbosa, F.; Mergler, D. Visual acuity in fish consumers of the Brazilian Amazon: Risks and benefits from local diet. Public Health Nutr. 2011, 14, 2236-2244. [CrossRef] [PubMed]

62. Fillion, M.; Philibert, A.; Mertens, F.; Lemire, M.; Passos, C.J.; Frenette, B.; Guimaraes, J.R.; Mergler, D. Neurotoxic sequelae of mercury exposure: An intervention and follow-up study in the Brazilian Amazon. EcoHealth 2011, 8, 210-222. [CrossRef] [PubMed]

63. Khoury, E.D.T.; Souza, G.D.S.; Silveira, L.C.D.L.; Costa, C.A.D.; Araújo, A.A.D.; Pinheiro, M.D.C.N. Neurological manifestations in riverine populations from areas exposed to mercury in the Brazilian Amazon. Cad. Saude Publica 2013, 29, 2307-2318. [CrossRef] [PubMed]

64. Khoury, E.D.T.; Souza, G.S.; Silveira, L.C.L.; Costa, C.A.; Araújo, A.A.; Pinheiro, M.C.N. Manifestações neurológicas em ribeirinhos de áreas expostas ao mercúrio na Amazônia brasileira. Cad. Saude Publica 2013, 29, 2307-2318. [CrossRef] [PubMed]

65. Cardoso, N.A.; Hoshino, A.C.H.; Perez, M.A.; Bastos, W.R.; Carvalho, D.P.D.; Câmara, V.D.M. Zumbido em uma população ribeirinha exposta ao metilmercúrio. Audiol. Commun. Res. 2014, 19, 40-44. [CrossRef]

66. Hoshino, A.; Pacheco-Ferreira, H.; Sanches, S.G.G.; Carvallo, R.; Cardoso, N.; Perez, M.; Câmara, V.D.M. Mercury exposure in a riverside Amazon population, Brazil: A study of the ototoxicity of methylmercury. Int. Arch. Otorhinolaryngol. 2015, 19, 135-140. [CrossRef] [PubMed] 
67. Costa Junior, J.M.F.; Lima, A.A.D.S.; Rodrigues Junior, D.; Khoury, E.D.T.; Souza, G.D.S.; Silveira, L.C.D.L.; Pinheiro, M.D.C.N. Emotional and motor symptoms in riverside dwellers exposed to mercury in the Amazon. Rev. Bras. de Epidemiol. 2017, 20, 212-224. [CrossRef] [PubMed]

68. Arrifano, G.P.; Martín-Doimeadios, R.C.; Jiménez-Moreno, M.; Fernández-Trujillo, S.; Augusto-Oliveira, M.; Souza-Monteiro, J.R.; Macchi, B.M.; Alvarez-Leite, J.I.; do Nascimento, J.L.; Amador, M.T.; et al. Genetic susceptibility to neurodegeneration in amazon: Apolipoprotein e genotyping in vulnerable populations exposed to mercury. Front. Genet. 2018, 9, 285. [CrossRef]

69. Dos Santos Freitas, J.; Lacerda, E.M.; da Silva Martins, I.C.; Rodrigues, D., Jr.; Bonci, D.M.; Cortes, M.I.; Corvelo, T.C.; Ventura, D.F.; de Lima Silveira, L.C.; Pinheiro, M.D.; et al. Cross-sectional study to assess the association of color vision with mercury hair concentration in children from Brazilian Amazonian riverine communities. Neurotoxicology 2018, 65, 60-67. [CrossRef] [PubMed]

70. Domingues, M.M.; Cury, E.D.; de Araújo, A.A.; Junior, J.M.; Pinheiro, M.D. Somatosensory psychophysic losses in inhabitants of riverside communities of the Tapajós river basin, Amazonas, Brazil: The possible involvement of exposure to methylmercury. $J$. Neurol. Sci. 2019, 405, 255-256. [CrossRef]

71. Pinheiro, M.D.; Oikawa, T.; Vieira, J.L.; Gomes, M.S.; Guimarães, G.D.; Crespo-López, M.E.; Müller, R.C.; Amoras, W.W.; Ribeiro, D.R.; Rodrigues, A.R.; et al. Comparative study of human exposure to mercury in riverside communities in the Amazon region. Braz. J. Med. Biol. Res. 2006, 39, 411-414. [CrossRef] [PubMed]

72. Marinho, J.S.; Lima, M.O.; Santos, E.C.; de Jesus, I.M.; Pinheiro, M.D.; Alves, C.N.; Muller, R.C. Mercury speciation in hair of children in three communities of the Amazon, Brazil. BioMed Res. Int. 2014, 2014, 945963. [CrossRef]

73. Takaoka, S.; Fujino, T.; Hotta, N.; Ueda, K.; Hanada, M.; Tajiri, M.; Inoue, Y. Signs and symptoms of methylmercury contamination in a First Nations community in Northwestern Ontario, Canada. Sci. Total Environ. 2014, 468-469, 950-957. [CrossRef]

74. Jackson, A.C. Chronic Neurological Disease Due to Methylmercury Poisoning. Can. J. Neurol. Sci. 2018, 45, 620-623. [CrossRef]

75. Cariccio, V.L.; Samà, A.; Bramanti, P.; Mazzon, E. Mercury Involvement in Neuronal Damage and in Neurodegenerative Diseases. Biol. Trace Elem. Res. 2019, 187, 341-356. [CrossRef] [PubMed]

76. Weiss, B.; Clarkson, T.W.; Simon, W. Silent latency periods in methylmercury poisoning and in neurodegenerative disease. Environ. Health Perspect. 2002, 110 (Suppl. 5), 851-854. [CrossRef] [PubMed]

77. Souza-Talarico, J.N.; de Carvalho, A.P.; Brucki, S.M.; Nitrini, R.; Ferretti-Rebustini, R.E. Dementia and Cognitive Impairment Prevalence and Associated Factors in Indigenous Populations: A Systematic Review. Alzheimer Dis. Assoc. Disord. 2016, 30, 281-287. [CrossRef] [PubMed]

78. Folstein, M.F.; Folstein, S.E.; McHugh, P.R. Mini-mental state. A practical method for grading the cognitive state of patients for the clinician. J. Psychiatr. Res. 1975, 12, 189-198. [CrossRef] 